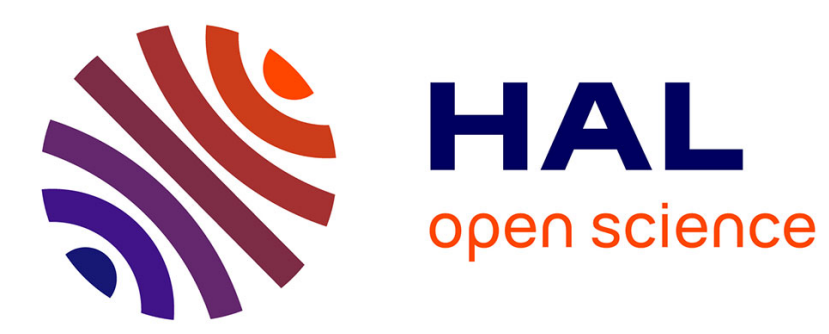

\title{
Somatic Mutations in the proto-oncogene in Sporadic Medullary Thyroid Carcinomas
}

S. Dvorakova, E. Vaclavikova, V. Sykorova, J. Vcelak, Z. Novak, J. Duskova, A. Ryska, J. Laco, J. Cap, D. Kodetova, et al.

\section{- To cite this version:}

S. Dvorakova, E. Vaclavikova, V. Sykorova, J. Vcelak, Z. Novak, et al.. Somatic Mutations in the proto-oncogene in Sporadic Medullary Thyroid Carcinomas. Molecular and Cellular Endocrinology, 2008, 284 (1-2), pp.21. 10.1016/j.mce.2007.12.016 . hal-00531978

\section{HAL Id: hal-00531978 \\ https://hal.science/hal-00531978}

Submitted on 4 Nov 2010

HAL is a multi-disciplinary open access archive for the deposit and dissemination of scientific research documents, whether they are published or not. The documents may come from teaching and research institutions in France or abroad, or from public or private research centers.
L'archive ouverte pluridisciplinaire HAL, est destinée au dépôt et à la diffusion de documents scientifiques de niveau recherche, publiés ou non, émanant des établissements d'enseignement et de recherche français ou étrangers, des laboratoires publics ou privés. 


\section{Accepted Manuscript}

Title: Somatic Mutations in the RET proto-oncogene in Sporadic Medullary Thyroid Carcinomas

Authors: S. Dvorakova, E. Vaclavikova, V. Sykorova, J. Vcelak, Z. Novak, J. Duskova, A. Ryska, J. Laco, J. Cap, D. Kodetova, R. Kodet, L. Krskova, P. Vlcek, J. Astl, D. Vesely,

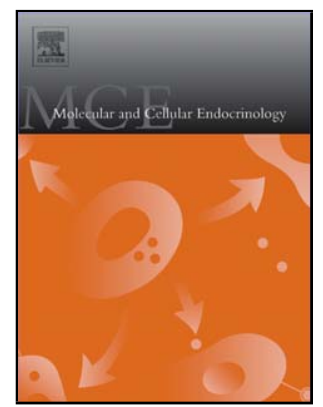

B. Bendlova

PII:

S0303-7207(08)00003-8

DOI: doi:10.1016/j.mce.2007.12.016

Reference: MCE 6781

To appear in: Molecular and Cellular Endocrinology

Received date: 29-10-2007

Revised date:

Accepted date:

22-12-2007

Please cite this article as: Dvorakova, S., Vaclavikova, E., Sykorova, V., Vcelak, J., Novak, Z., Duskova, J., Ryska, A., Laco, J., Cap, J., Kodetova, D., Kodet, R., Krskova, L., Vlcek, P., Astl, J., Vesely, D., Bendlova, B., Somatic Mutations in the RET proto-oncogene in Sporadic Medullary Thyroid Carcinomas, Molecular and Cellular Endocrinology (2007), doi:10.1016/j.mce.2007.12.016

This is a PDF file of an unedited manuscript that has been accepted for publication. As a service to our customers we are providing this early version of the manuscript. The manuscript will undergo copyediting, typesetting, and review of the resulting proof before it is published in its final form. Please note that during the production process errors may be discovered which could affect the content, and all legal disclaimers that apply to the journal pertain. 


\section{Somatic Mutations in the $R E T$ proto-oncogene in Sporadic Medullary Thyroid}

\section{Carcinomas}

S. Dvorakova ${ }^{1}$, E. Vaclavikova ${ }^{1}$, V. Sykorova ${ }^{1}$, J. Vcelak ${ }^{1}$, Z. Novak ${ }^{2}$, J. Duskova ${ }^{3}$, A. Ryska $^{4}$, J. Laco ${ }^{4}$, J. Cap ${ }^{5}$, D. Kodetova ${ }^{6}$, R. Kodet ${ }^{6}$, L. Krskova ${ }^{6}$, P. Vlcek ${ }^{7}$, J. Astl ${ }^{8}$, D. Vesely $^{8}$, B. Bendlova ${ }^{1}$

${ }^{1}$ Dept. of Molecular Endocrinology, Institute of Endocrinology, Prague

${ }^{2}$ Dept. of Clinical Endocrinology, Institute of Endocrinology, Prague

${ }^{3}$ Institute of Pathology, $1{ }^{\text {st }}$ Medical Faculty, Charles University, Prague

${ }^{4}$ Dept. of Pathology, Charles University Faculty of Medicine and University Hospital, Hradec Kralove

${ }^{5} 2^{\text {nd }}$ Department of Internal Medicine, Charles University Faculty of Medicine and University Hospital, Hradec Kralove

${ }^{6}$ Institute of Pathology and Molecular Medicine, $2^{\text {nd }}$ Medical Faculty, Charles University, Prague

${ }^{7}$ Dept. of Nuclear Medicine and Endocrilonogy, $2^{\text {nd }}$ Medical Faculty, Charles University, Prague

${ }^{8}$ Dept. of ENT and Head and Neck Surgery, $1^{\text {st }}$ Medical Faculty, Charles University, Prague

\section{Corresponding author:}

Dr. Sarka Dvorakova, $\mathrm{PhD}$

Dept. of Molecular Endocrinology, Institute of Endocrinology

Narodni 8

116 94, Prague 1, Czech Republic

Tel.: +4200224905301

Fax: +420224905305

e-mail: sarka@obloha.cz 
Keywords: RET proto-oncogene, Medullary Thyroid Carcinoma, somatic mutation, genetics, prognosis

\section{Summary:}

The frequency and prognostic relevance of RET proto-oncogene somatic mutations in sporadic medullary thyroid carcinoma (MTC) remain controversial. In order to study somatic mutations in the RET proto-oncogene in sporadic MTCs found in the Czech population and to correlate these mutations with clinical and pathological characteristics, we investigated 48 truly sporadic MTCs by sequencing classical risk exons 10,11, 13, 14, 15 and 16. From the 48 tumors studied, $23(48 \%)$ had somatic mutation in the RET proto-oncogene in exons 10 , 11,15 or 16 . The classical somatic mutation Met918Thr in exon 16 was only found in 13 tumors $(27 \%)$. In 5 cases, multiple somatic mutations and deletions were detected. A statistically significant correlation between the presence of somatic mutation with more advanced pathological TNM stages was observed. Other clinical and pathological characteristics did not show any statistical significant association with the presence or absence of somatic mutation.

\section{Introduction:}

Medullary thyroid carcinoma (MTC) is a malignant tumor of the neural crest-derived parafollicular C cells. It occurs in both sporadic (75\%) and familial (25\%) forms. The familial forms occur either as a familial MTC (FMTC) or as a part of multiple endocrine neoplasia type 2 (MEN 2) syndromes. Mutations of the RET proto-oncogene are involved in the pathogenesis of not only MEN 2 syndromes and FMTC, but also of sporadic MTC. Apart from germline mutations in hereditary syndromes, various somatic mutations located in the tyrosine kinase domain and cysteine-rich domain of the RET proto-oncogene are also found in 
truly sporadic MTC. The somatic mutation Met918Thr in exon 16 in the intracellular tyrosine kinase domain as well as minor somatic mutations at codons 768 in exon 13 and 883 in exon 15 have been diagnosed in approximately one-third of sporadic MTCs (Hofstra et al. 1994, Eng et al. 1995, Marsh et al. 1996). Only a few mutations at codons 630 and 634 and deletions have been reported in the extracellular cysteine-rich domain (Romei et al. 1996, Donis-Keller et al. 1993, Hofstra et al. 1996, Ceccherini et al. 1997, Alemi et al. 1997).

The use of a detected somatic mutation as a marker of prognosis has been questioned, its value has been debated with inconclusive results in different studies. Some studies have shown a significant difference in the clinical outcome of sporadic MTC based on the presence of a codon 918 mutation (Zedenius et al. 1995, Jhiang et al. 1996, Romei et al. 1996, Wohllk et al. 1996), whereas others reported no significant difference.

In this report, we present results from the detection of somatic mutations of the RET proto-oncogene with genotype-phenotype correlation analysis in a cohort of 48 patients with sporadic MTCs.

\section{Materials and Methods:}

\section{Patients}

Tumor tissues were formalin-fixed and paraffin embedded (46 tissues) or fresh frozen (6 tissues). The paraffin blocks with tumor tissue were retrieved from the authors' archives (R.K., A.R. and J.D.). All patients had undergone surgery (total thyroidectomy) between 1987 and 2004.

A total of 52 apparently sporadic MTC cases were analyzed for RET gene mutations. These patients had no family history of hereditary MTC, pheochromocytoma, parathyroid disease, skeletal abnormalities, mucosal neuromas or Hirschsprung's disease. Table 1 describes the truly sporadic MTC patients' data. 
On the basis of our genetic testing, in four cases of the $52(7.7 \%)$ apparently clinically sporadic MTC, germline mutations were found: in exon 10 Cys609Tyr, in exon 13 Glu768Asp, in exon 14 Val804Met and a double germline mutation in exons 10 Cys620Phe and 13 Tyr791Phe. These patients were reclassified as FMTC and excluded from our statistical analysis and descriptions.

In addition, four MEN 2 cases were included as positive controls for methodological reasons (MTC tissues obtained from two MEN 2A and two MEN 2B patients).

\section{Clinical and pathological data}

Additional clinical and pathological data was collected including sex, age at diagnosis, serum calcitonin (CT) levels after operation and at the last control (RIA kit, DFL-1200, USA; normal values were considered under $40 \mathrm{pg} / \mathrm{ml}$ and increased above $40 \mathrm{pg} / \mathrm{ml}$ ), pathological TNM classification at the time of operation, presence of local and distant metastases during follow-up period, clinical outcome, length of follow-up period, disease free interval, tumor size (as the maximum diameter of the tumor), tumor differentiation (defined as well/poorly differentiated according to Shan et al. 1998), vascular invasion and the presence of amyloid and the presence of necrosis.

In the pTNM classification (accordingly to the $6^{\text {th }}$ edition of AJCC - American Joint Committee on Cancer, Greene et al. 2002) the T1 category represents tumors $20 \mathrm{~mm}$ or less in its greatest dimension and limited to the thyroid, T2 tumors between 21 and $40 \mathrm{~mm}$ in its greatest dimension and limited to the thyroid, T3 tumors more than $41 \mathrm{~mm}$ in its greatest dimension and limited to the thyroid or with minimal extrathyroid extension and T4 tumors of any size extending beyond the thyroid capsule. 
Medullary carcinomas were usually unencapsulated, showing infiltrative growth into surrounding parenchyma. They were composed mostly of polygonal and spindled cells with polymorphous nuclei, bi- or multinucleated cells were present as well.

\section{Genetic analysis}

The mutation analysis was performed with the informed consent of each patient. DNA was extracted in each case from fresh or formalin-fixed paraffin-embedded tumor tissue and corresponding non-neoplastic thyroid tissue or peripheral blood leukocytes by modified phenol-chloroform isolation protocol as described previously (Jindrichova et al. 2003). Each tumor sample included in this study was confirmed to contain a minimum of $70 \%$ tumor cells. PCR amplifications of exons 10,11,13,14, 15 and 16 and subsequent double-stranded fluorescent sequencing were performed according to our previously described procedure (Jindrichova et al. 2004).

\section{Statistical analysis:}

For statistical evaluation of the data chi-squared tests, Fisher exact tests and MannWhitney tests were used. Values of $\mathrm{p}<0.05$ were considered to be statistically significant.

\section{Results:}

\section{Frequency of somatic mutations in sporadic MTCs found in the Czech population}

Germline mutations (RET proto-oncogene mutation detected in tumor tissue as well as in the normal control tissue or blood) were present in 4 out of $52(7.7 \%)$ cases of clinically apparently sporadic MTC; these cases were excluded from further analysis. Forty eight tumors carrying no germline mutation represent truly sporadic MTC. In 23 of them (48\%) somatic mutations of the RET proto-oncogene were revealed. The detection rate and types of 
somatic mutations are presented in Table 2. In 13 cases (27\%) the classical somatic mutation Met918Thr in exon 16 was found. Mutations in exon 16 were also involved in another 4 cases $(8 \%)$. Seven tumors carried a somatic mutation in exons 10,11 or 15 . The $6 \mathrm{bp}$ deletion of codons 632-633 in exon 11 was detected in 3 of these patients. Multiple mutations were found in 2 MTCs. These two cases were reported by us earlier (Dvorakova et al. 2006). In 25 samples $(52 \%)$ no mutations in the six screened risk exons of the RET proto-oncogene were detected.

\section{Genotype-phenotype correlation}

Table 3 summarizes clinical and pathological characteristics with respect to the presence/absence of somatic mutation. As to sex distribution, there are more females in the group without somatic mutation in comparison to the group with detected somatic mutation $(62.1 \%$ vs. $37.9 \%$, Fisher exact test, n.s.). The groups did not differ in the age of the patient at diagnosis. Pathological TNM classification was significantly worse in patients with somatic mutation (T1, T2, T3 and T4 in groups with and without mutation; Fisher exact test, $\mathrm{p}=0.022)$. If $\mathrm{T} 1, \mathrm{~T} 2$ and $\mathrm{T} 3$ classes were grouped and compared with the $\mathrm{T} 4$ class, the statistical significance was much more obvious (Fisher exact test, $\mathrm{p}=0.003$ ). Interestingly, all 3 patients with the deletion in exon 11 belong to the T4 classification. Also, the proportion of patients with increased calcitonin levels after operation and at the last checkup was higher in the group with detected somatic mutation in comparison to those without mutation but the difference did not reach statistical significance (Fisher exact test, n.s.). There is a lower rate of relapse among patients who did not exhibit somatic mutation (40\% vs. $60 \%)$ and these patients had a better clinical outcome in comparison to the RET mutation carriers (Fisher exact test, n.s.). When analyzing tumor size, tumor differentiation, invasion of vessels, presence of amyloid and/or necrosis, no statistically significant parameter was identified, but there is a trend 
towards worse variants given with somatic mutations (Fisher exact test or Mann-Whitney test, n.s.).

\section{Discussion:}

The role of the RET proto-oncogene in the development of sporadic forms of MTC is still not fully understood. The rate of RET somatic mutations has been found to vary from $12 \%$ to $100 \%$ in published literature (Zedenius et al. 1994, Romei et al. 1996, Jhiang et al. 1996, Marsh et al. 1996, Marsh et al. 2003, Shan et al. 1998, Uchino et al. 1998, Uchino et al. 1999, Scurini et al. 1998, Bockhorn et al. 1999, Hofstra et al. 1994, Bugalho et al. 1997).

Several studies reported a high incidence of somatic Met918Thr RET proto-oncogene mutation in sporadic MTC. The frequency of this major somatic mutation has varied greatly in literature from 23\% to 85\% (Zedenius et al. 1994, Romei et al. 1996, Marsh et al. 1996, Shan et al. 1998, Uchino et al. 1998, Scurini et al. 1998, Bockhorn et al. 1999, Hofstra et al. 1994, Bugalho et al. 1997). However, the reason for these variations is still not clear. Some authors have suggested that the difference in frequency is due to ethnic or environmental factors or simply due to differences in detection methods.

It is hypothesized that somatic mutations of the RET proto-oncogene cause a continuous inappropriate activation of the RET protein, which may lead to MTC development. The Met at codon 918 is highly conserved and lies within the substrate binding pocket of the central catalytic core of the tyrosine kinase domain. Met918Thr mutation causes constitutive activation of tyrosine kinase activity as the affinity of the substrate binding pocket is altered and thus phosphorylation is increased. In fact, the mutation at codon 918 perhaps is the starting event of these neoplasms (Santoro et al. 1995, Eng et al. 1996).

The herein reported cohort is one of the largest single-country studies, we analyzed 48 truly sporadic MTC and found somatic mutations in $48 \%$ of these cases. In accordance with 
other reported studies, the most common mutation was identified at codon 918 with a detection rate of $27 \%$ which represents $56.5 \%$ of all detected mutations.

In some cohorts, besides the Met918Thr mutation, other minor mutations in exons 10 , 11, 12, 13 and 15 were detected (Scurini et al. 1998, Bugalho et al. 1997, Uchino et al. 1999). These somatic mutations are rarely found in patients in literature. It may be also due to the fact that not all laboratories have screened all risk exons of the RET proto-oncogene. We found other types of mutations (exon 16: Thr930Met, Ser922Pro, Gly911Asp, Glu921Lys; exon 11: Cys630Arg, del 6bp 632-633 codons; exon 10: Val591Ile; exon 15: Ala883Phe, Ala 883 Ser) in $20,8 \%$ of the tumors.

Our mutational screening also revealed multiple mutations (exon 16: Gly911Asp+Met918Thr+Glu921Lys; exon 10+exon16: Val591Ile+Met918Thr) in 2 cases (4.2\%), which were described in detail previously (Dvorakova et al. 2006). Although single somatic RET mutation is sufficient for MTC development, it is not clear why multiple mutations occur only in a very few cases (Marsh et al. 1996). We found no different biological or clinical features of tumors in these two cases compared to tumors with single somatic mutation. It is possible that some cell populations require additional RET alteration. Eng et al. 1996 and 1998 have shown previously that approximately 80\% of sporadic MTCs had several subpopulations with different types of somatic RET mutations.

In 3 cases $(6.1 \%)$ a 6bp in-frame deletion that removed codons Glu632 and Leu633 in exon 11 was identified. The three carriers of this deletion had the most aggressive tumors in our study having T4 classification. These findings are in accordance to the data reported by Bongarzone et al. 1999 where the authors described the strong transforming activity of this mutation. Deletion of codons 632-633 more effectively activated the RET gene in comparison to the Cys634Arg missense mutation. Deletion of codons 632-633 induced stable receptor dimer formation in the absence of a ligand. This correlated with the clinically more advanced 
stage of the corresponding tumor, characterized by an unusually aggressive progression with multiple and recurrent metastases. On the other hand, Ret protein with del632-633 proceed more slowly to the cell surface than with Cys634Arg due to precursor retention in the endoplasmic reticulum.

Other types of deletions of nucleotides have been found in certain sporadic MTCs - in addition to those described above, a 3 bp deletion including codon 633 , 24bp deletion including codon 634 combined with a 6bp insertion, 48bp del592-607, 27bp del611-618 or 612-620 and 12 bp del898-901 have been reported (Donis-Keller et al. 1993, Romei et al. 1996, Marsh et al. 1997, Hofstra et al. 1996, Ceccherini et al. 1997, Alemi et al. 1997, Kalinin et al. 1998, Oriola et al. 2002, Uchino et al. 1999).

Among our 48 truly sporadic MTCs, no mutations in the 6 classical risk exons were revealed in 25 of the tumors $(52,1 \%)$. There are several possibilities as to the explanation of this fact: 1) mutations and/or polymorphisms able to cause MTC were present in other exons besides those we examined in this study are present. 2) factors other than somatic mutations of the RET proto-oncogene can play an important role in sporadic MTCs progression. Although RET mutation is most likely a sufficient event to cause C-cell hyperplasia, the precursor lesion to MTC, tumor progression is thought to be a result of a clonal expansion caused by the accumulation of other somatic events (Musholt et al. 2005; Montani et al. 2005; Gimm et al. 2001a, Gimm et al. 2001b). Research has found that in more than half of studied cases, chromosomal imbalances are present (Frisk et al. 2001, Marsh et al. 2003). MTC is a relatively genetically stable tumor, and chromosomal regions $19 \mathrm{q}, 19 \mathrm{p}, 13 \mathrm{q}$ and $11 \mathrm{q}$ may be involved in MTC carcinogenesis. Mutations of other candidate genes could be also involved in the pathogenesis of sporadic MTC (Musholt et al. 2005, Costa et al. 2005; Montani et al. 2005; Elisei et al. 2004; Marsh et al. 2003; Gimm et al. 2001a, Gimm et al. 2001b, Ruiz et al. 2001). 
The use of detection of the somatic mutation of the RET proto-oncogene as a marker of prognosis has been discussed in literature. A significant correlation between the presence of somatic mutation with poor clinical outcome, distant metastasis and tumor recurrence was found, as well as concordance between positive RET immunohistochemical staining and the demonstration of the codon 918 mutation (Romei et al. 1994, Jhiang et al. 1996, Zedenius et al. 1994, Eng et al. 1998). We also found correlation between the presence of somatic mutation with more advanced pathological TNM stage. In our patients carrying somatic mutation, other trends (but not statistically significant) were apparent as well - increased CT values, worse clinical outcome and larger size of tumors with mutation. On the other hand, there are studies reporting no significant differences in parameters as the age at diagnosis, tumor size, tumor differentiation, presence or absence of metastasis, MTC-related morbidity, recurrence or prognosis base-line CT levels at diagnosis or most recent follow-up, with the presence of positive RET immunostaining between somatic mutation carriers and non-carriers (Marsh et al. 1996, Komminoth et al. 1995, Shan et al. 1998, Maeda et al. 1995, Uchino et al. 1998, Uchino et al. 1999, Scurini et al. 1998, Bockhorn et al. 1999).

These results justify the use of RET tyrosine kinase inhibitors as a promising therapy (De Groot et al. 2006). Antitumorous drugs are small tyrosine kinase inhibitors molecules that compete with ATP and thus block autophosphorylation and kinase activity and signal transduction. The most promising candidate from tested drugs seems to be anilinoquinazoline ZD6474, because it effectively blocks phosphorylation and signaling of the RET protein. Two other small tyrosine kinase inhibitors molecules, the pyrazolopyrimidine compounds PP1 and PP2, have been tested and found to be effective in therapeutic concentrations. The number of discovered small organic compounds that block RET tyrosine phosphorylation is still increasing and we hope that in the near future it can be used in the treatment of RET positive tumors and perhaps it will also be involved in a preventive strategy for treatment of patients 
with somatic or germline mutations in the RET proto-oncogene (Carlomagno et al. 2004, Carlomagno et al. 2002, Cohen et al. 2002).

Our data suggest that the screening of tumor DNA for RET somatic mutations not only may help to distinguish the sporadic MTC from the familial forms with important clinical and predictive consequences, but it is also useful in the prediction of clinical outcome and therapy of certain sporadic tumors depending upon the presence and type of RET somatic mutation.

\section{References}

Alemi, M., Lucas, S.D., Sallstrom, J.F., Bergholm, U., Akerstrom, G., Wilander, E., 1997. A complex nine base pair deletion in RET exon 11 common in sporadic medullary thyroid carcinoma. Oncogene 14, 2041-2045.

Bockhorn, M., Frilling, A., Kalinin, V., Schröder, S., Broelsch, C.E., 1999. No correlation between RET immunostaining and the codon 918 mutation in sporadic medullary thyroid carcinoma. Langenbecks Arch. Surg. 384, 60-64.

Bongarzone, I., Vigano, E., Alberti, L., Mondellini, P., Uggeri, M., Pasini, B., Borrello, M.G., Pierotti, M.A., 1999. The Glu632-Leu633 deletion in cysteine rich domain of Ret induces constitutive dimerization and alters the processing of the receptor protein. Oncogene 18, 4833-4838.

Bugalho, M.J., Frade, J.P., Santos, J.R., Limbert, E., Sobrinho, L., 1997. Molecular analysis of the RET proto-oncogene in patients with sporadic medullary thyroid carcinoma: a novel point mutation in the extracellular cysteine-rich domain. Eur. J. Endocrinol. 136, 423-426.

Carlomagno, F., Santoro, M., 2004. Identification of RET kinase inhibitors as potential new treatment for sporadic and inherited thyroid cancer. J. Chemother. 16, 49-51. 
Carlomagno, F., Vitagliano, D., Guida, T., Napolitano, M., Vecchio, G., Fusco, A., Gazit, A., Levitzki, A., Santoro, M., 2002. The kinase inhibitor PP1 blocks tumorigenesis induced by RET oncogenes. Cancer Res. 62, 1077-1082.

Ceccherini, I., Pasini, B., Pacini, F., Gullo, M., Bongarzone, I., Romei, C., Santamaria, G., Matera, I., Mondellini, P., Scopsi, L., Pinchera, A., Pierotti, M.A., Romeo, G., 1997. Somatic in frame deletions not involving juxtamembranous cysteine residues strongly activate the RET proto-oncogene. Oncogene 14, 2609-2612.

Cohen, M.S., Hussain, H.B., Moley, J.F., 2002. Inhibition of medullary thyroid carcinoma cell proliferation and RET phosphorylation by tyrosine kinase inhibitors. Surgery 132, 960966.

Costa, P., Domingues, R., Sobrinho, L.G., Bugalho, M.J., 2005. RET polymorphisms and sporadic medullary thyroid carcinoma in a Portuguese population. Endocrine 27, 239-243.

De Groot, J.W.B., Links, T.P., Plukker, J.T.M., Lips, C.J.M., Hofstra, R.M.W., 2006. RET as a Diagnostic and Therapeutic Target in Sporadic and Hereditary endocrine tumors. Endocr. Rev. 27, 535-560.

Donis-Keller, H., Dou, S., Chi, D., Carlson, K.M., Toshima, K., Lairmore, T.C., Howe, J.R., Moley, J.F., Goodfellow, P., Wells, S.A. Jr., 1993. Mutations in the RET proto-oncogene are associated with MEN 2A and FMTC. Hum. Mol. Genet. 2, 851-856.

Dvorakova, S., Vaclavikova, E., Sykorova, V., Duskova, J., Vlcek, P., Ryska, A., Novak, Z., Bendlova, B., 2006. New multiple somatic mutations in the RET proto-oncogene associated with a sporadic medullary thyroid carcinoma. Thyroid 16, 311-316.

Elisei, R., Cosci, B., Romei, C., Bottici, V., Sculli, M., Lari, R., Barale, R., Pacini, F., Pinchera, A., 2004. RET exon 11 (G691S) polymorphism is significantly more frequent in sporadic medullary thyroid carcinoma than in the general population. J. Clin. Endocrinol. Metab. 89, 3579-3584. 
Eng, C., Mulligan, L.M., Smith, D.P., Healey, C.S., Frilling, A., Raue, F., Neumann, H.P., Pfragner, R., Behmel, A., Lorenzo, M.J., 1995. Mutation of the RET protooncogene in sporadic medullary thyroid carcinoma. Genes Chromosomes Cancer 12, 209-212.

Eng, C., Smith, D.P., Mulligan, L.M., Healey, C.S., Zvelebil, M.J., Stonehouse, TJ., Poder, M.A., Jackson, C.E., Waterfield, M.D., Poder, B.A.J., 1995. A novel point mutation in the tyrosine kinase domain of the RET proto-oncogene in sporadic medullary thyroid carcinoma and in a family with FMTC. Oncogene 10, 509-513.

Eng, C., Mulligan, L.M., Healey, C.S., Houghton, C., Frilling, A., Raue, F., Thomas, G.A., Ponder, B.A., 1996. Heterogeneous mutation of the RET proto-oncogene in subpopulations of medullary thyroid carcinoma. Cancer Res. 56, 2167-2170.

Eng, C., Thomas, G.A., Neuberg, D.S., Mulligan, L.M., Healey, C.S., Houghton, C., Frilling, A., Raue, F., Williams, E.D., Ponder, B.A.,1998. Mutation of the RET proto-oncogene is correlated with RET immunostaining in subpopulations of cells in sporadic medullary thyroid carcinoma. J. Clin. Endocrinol. Metab. 83, 4310-4313.

Frisk, T., Zedenius, J., Lundberg, J., Wallin, G., Kytölä, S., Larsson, C., 2001. CGH alterations in medullary thyroid carcinomas in relation to the RET M918T mutation and clinical outcome. Int. J. Oncol. 18, 1219-1225.

Gimm, O., Dziema, H., Brown, J., Hoang-Vu, C., Hinze, R., Dralle, H., Mulligan, L.M., Eng, C.. 2001. Over-representation of a germline variant in the gene encoding RET co-receptor GFRalpha-1 but not GFRalpha-2 or GFRalpha-3 in cases with sporadic medullary thyroid carcinoma. Oncogene 20, 2161-2170.

Gimm, O., Dziema, H., Brown, J., de la Punte, A., Hoang-Vu, C., Dralle, H., Plass, C., Eng, C., 2001. Mutation analysis of NTRK2 and NTRK3, encoding 2 tyrosine kinase receptors, in sporadic human medullary thyroid carcinoma reveals novel sequence variants. Int. J. Cancer $92,70-74$. 
Greene, F.L., Page, D.L., Fleming, I.D., Fritz, A.G., Balch, C.M., Halley, D.G., Morrow, M., 2002. AJCC Cancer Staging Handbook: TNM Classification of Malignant Tumors, 6th ed., New York: Springer-Verlag.

Hofstra, R.M., Landsvater, R.M., Ceccherini, I., Stulp, R.P., Stelwagen, T., Luo, Y., Pasini, B., Hoppener, J.W., van Amstel, H.K., Romeo, G., 1994. A mutation in the RET protooncogene associated with multiple endocrine neoplasia type 2B and sporadic medullary thyroid carcinoma. Nature 367, 375-376.

Hofstra, R.M., Stelwagen, T., Stulp, R.P., de Jong, D., Hulsbeek, M., Kamsteeg, E.J., van den Berg, A., Landsvater, R.M., Vermey, A., Molenaar, W.M., Lips, C.J., Buys, C.H., 1996. Extensive mutation scanning of RET in sporadic medullary thyroid carcinoma and of RET and VHL in sporadic pheochromocytoma reveals involvement of these genes in only a minority of cases. J. Clin. Endocrinol. Metab. 81, 2881-2884.

Jhiang, S.M., Fithian, L., Weghorst, C.M., Clark, O.H., Falko, J.M., O'Dorisio, T.M., Mazzaferri, E.L., 1996. RET mutation screening in MEN2 patients and discovery of a novel mutation in a sporadic medullary thyroid carcinoma. Thyroid 6, 115-121.

Jindrichova, S., Kodet, R., Krskova, L., Vlcek, P., Bendlova, B., 2003. The newly detected mutations in the RET proto-oncogene in exon 16 as a cause of sporadic medullary thyroid carcinoma. J. Mol. Med. 81, 819-823.

Jindrichova, S., Vcelak, J., Vlcek, P., Neradilova, M., Nemec, J., Bendlova, B., 2004. Screening of six risk exons of the RET proto-oncogene in families with medullary thyroid carcinoma in the Czech Republic. J. Endocrinol. 183, 257-265.

Kalinin, V., Frilling, A., 1998. 27-bp Deletion in the RET proto-oncogene as a somatic mutation associated with medullary thyroid carcinoma. J. Mol. Med. 76, 365-367. 
Kalinin VN, Amosenko FA, Shabanov MA, Lubchenko LN, Hosch SB, Garkavtseva RF, Izbicki JR, 2001. Three novel mutations in the RET proto-oncogene. J. Mol. Med. 79, 609612.

Komminoth, P., Muletta-Feurer, S., Saremaslani, P., Kunz, E.K., Matias-Guiu, X., Hiort, O., Schroder, S., Seelentag, W.K., Roth, J., Heitz, P.U., 1995. Molecular Diagnosis of Multiple Endocrine Neoplasia (MEN) in Paraffin-Embedded Specimens. Endocr. Pathol. 6, 267-278. Komminoth, P., Kunz, E.K., Matias-Guiu, X., Hiort, O., Christiansen, G., Colomer, A., Roth, J., Heitz, P.U., 1995. Analysis of RET protooncogene point mutations distinguishes heritable from nonheritable medullary thyroid carcinomas. Cancer 76, 479-489.

Maeda, S., Namba, H., Takamura, N., Tanigawa, K., Takahashi, M., Noguchi, S., Nagataki, S., Kanematsu, T., Yamashita, S., 1995. A single missense mutation in codon 918 of the RET proto-oncogene in sporadic medullary thyroid carcinomas. Endocr. J. 42, 245-250.

Marsh, D.J., Learoyd, D.L., Andrew, S.D., Krishnan, L., Pojer, R., Richardson, A.L., Delbridge, L., Eng, C., Robinson, B.G., 1996. Somatic mutations in the RET proto-oncogene in sporadic medullary thyroid carcinoma. Clin. Endocrinol. (Oxf.) 44, 249-257.

Marsh, D.J., Theodosopoulos, G., Martin-Schulte, K., Richardson, A.L., Philips, J., Röher, H.D., Delbridge, L., Robinson, B.G., 2003. Genome-wide copy number imbalances identified in familial and sporadic medullary thyroid carcinoma. J. Clin. Endocrinol. Metab. 88, 18661872.

Montani, M., Schmidt, A.M., Schmidt, S., Lochem, T., Saremaslani, P., Hertz, P.U., Komminoth, P., Perren, A., 2005. No mutations but an increased frequency of SDHx polymorphisms in patients with sporadic and familial medullary thyroid carcinoma. Endocr. Relat. Cancer 12, 1011-1016. 
Musholt, T.J., Hanack, J., Brehm, C., von Wasielewski, R., Musholt, P.B., 2005. Searching for non-RET molecular alterations in medullary thyroid carcinoma: expression analysis by mRNA differential display. World J. Surg. 29, 472-482.

Oriola, J., Halperin, I., Rivera-Fillat, F., Donis-Keller, H., 2002. The finding of a somaticdeletion in RET exon 15 clarified the sporadic nature of amedullary thyroid carcinoma suspected to be familial. J. Endocrinol. Invest. 25, 25-31.

Romei, C., Elisei, R., Pinchera, A., Ceccherini, I., Molinaro, E., Mancusi, F., Martino, E., Romeo, G., Pacini, F., 1996. Somatic mutations of the ret protooncogene in sporadic medullary thyroid carcinoma are not restricted to exon 16 and are associated with tumor recurrence. J. Clin. Endocrinol. Metab. 81, 1619-1622.

Ruiz, A., Antinolo, G., Fernandez, R.M., Eng, C., Marcos, I., Borrego, S., 2001. Germline sequence variant S836S in the RET proto-oncogene is associated with low level predisposition to sporadic medullary thyroid carcinoma in the Spanish population. Clin. Endocrinol. (Oxf.) 55, 399-402.

Santoro, M., Carlomagno, F., Romano, A., Bottaro, D.P., Nathan, N.A., Grieco, M., Fusco, A., Vecchio, G., Matýskova, B., Kraus, M.H., 1995. Activation of RET as a dominant transforming gene by germline mutations of MEN 2A and MEN 2B. Science 267, 381-383.

Scurini, C., Quadro, L., Fattoruso, O., Verga, U., Libroia, A., Lupoli, G., Cascone, E., Marzano, L., Paracchi, S., Busnardo, B., Girelli, M.E., Bellastella, A., Colantuoni, V., 1998. Germline and somatic mutations of the RET proto-oncogene in apparently sporadic medullary thyroid carcinomas. Mol. Cell. Endocrinol. 137, 51-57.

Shan, L., Nakamura, M., Nakamura, Y., Utsunomiya, H., Shou, N., Jiang, X., Jing, X., Yokoi, T., Kakudo, K., 1998. Somatic mutations in the RET protooncogene in Japanese and Chinese sporadic medullary thyroid carcinomas. Jpn. J. Cancer Res. 89, 883-886. 
Uchino, S., Noguchi, S., Adachi, M., Sato, M., Yamashita, H., Watanabe, S., Murakami, T.,

Toda, M., Murakami, N., Yamashita, H., 1998. Novel point mutations and allele loss at the RET locus in sporadic medullary thyroid carcinomas. Jpn. J. Cancer Res. 89, 411-418.

Uchino, S., Noguchi, S., Yamashita, H., Sato, M., Adachi, M., Yamashita, H., Watanabe, S., Ohshima, A., Mitsuyama, S., Iwashita, T., Takahashi, M., 1999. Somatic mutations in RET exons 12 and 15 in sporadic medullary thyroid carcinomas: different spectrum of mutations in sporadic type from hereditary type. Jpn. J. Cancer Res. 90, 1231-1237.

Wohllk, N., Cote, G.J., Bugalho, M.M., Ordonez, N., Evans, D.B., Goepfert, H., Khorana, S., Schultz, P., Richards, C.S., Gagel, R.F., 1996. Relevance of RET proto-oncogene mutations in sporadic medullary thyroid carcinoma. J. Clin. Endocrinol. Metab. 81, 3740-3745.

Zedenius, J., Larsson, C., Bergholm, U., Bovee, J., Svensson, A., Hallengren, B., Grimelius, L., Backdahl, M., Weber, G., Wallin, G., 1995. Mutations of codon 918 in the RET protooncogene correlate to poor prognosis in sporadic medullary thyroid carcinomas. J. Clin. Endocrinol. Metab. 80, 3088-3090.

Zedenius, J., Wallin, G., Hamberger, B., Nordenskjöld, M., Weber, G., Larsson, C.,1994. Somatic and MEN 2A de novo mutations identified in the RET proto-oncogene by screening of sporadic MTC:s. Hum. Mol. Genet. 3, 1259-1262.

\section{Acknowledgement}

The study was supported by grants IGA MH CR NR/9165-3 and GACR301/06/P425. 
Tab. 1: Detaily described patients'data

\begin{tabular}{|c|c|c|c|c|c|c|c|c|c|c|c|c|c|c|c|c|}
\hline 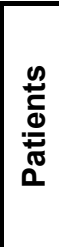 & ஸ̊ & 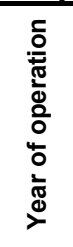 & 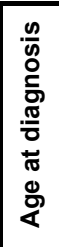 & 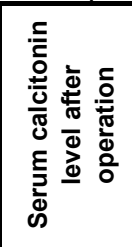 & 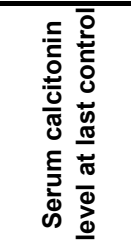 & 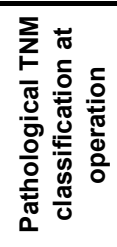 & 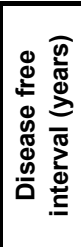 & 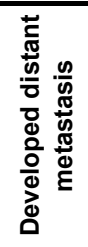 & 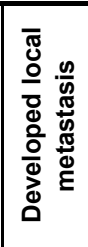 & 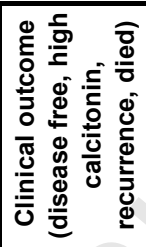 & 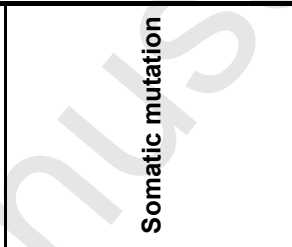 & 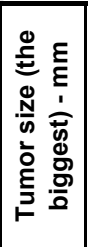 & 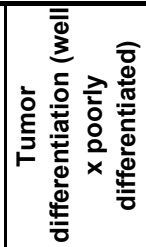 & 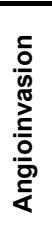 & 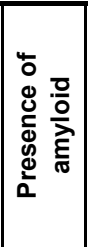 & $\begin{array}{l}\frac{\omega 0}{\omega 0} \\
\frac{0}{0} \\
\frac{0}{2}\end{array}$ \\
\hline 1 & $\mathrm{~F}$ & 2000 & 47 & normal & normal & T1NOM0 & 4 & no & $\mathrm{no}$ & $\mathrm{DF}$ & Met918Thr & 20 & $w$ & + & + & - \\
\hline 2 & $\mathrm{M}$ & 2000 & 49 & increased & increased & T2N2M0 & 3 & yes & yes & recurr. & Met918Thr & 28 & $w$ & + & + & - \\
\hline 3 & $\mathrm{~F}$ & 1987 & 42 & increased & increased & T4N1M1 & 1 & yes & yes & recurr. & $\begin{array}{l}\text { Met918Thr } \\
\end{array}$ & 40 & $p$ & + & + & + \\
\hline 4 & $\mathrm{~F}$ & 1999 & 64 & normal & normal & T1NOM0 & 5 & no & no & $\mathrm{DF}$ & Met918Thr & 9 & $p$ & - & - & + \\
\hline 5 & $\mathrm{M}$ & 2000 & 50 & increased & increased & T4N1M0 & 1 & no & yes & recurr. & Met918Thr & 20 & $w$ & + & + & - \\
\hline 6 & $\mathrm{~F}$ & 2000 & 15 & normal & normal & T2NOMO & 4 & no & no & $\mathrm{DF}$ & Met918Thr & 23 & $p$ & - & - & - \\
\hline 7 & $\mathrm{M}$ & 1999 & 57 & increased & increased & T4N1M0 & 0 & yes & yes & recurr. & Met918Thr & 45 & $\mathrm{p}$ & + & + & - \\
\hline 8 & $\mathrm{~F}$ & 2003 & 25 & increased & increased & T3N1M0 & 2 & yes & yes & recurr. & Met918Thr & 45 & $w$ & + & + & - \\
\hline 9 & $M$ & 2004 & 51 & increased & increased & T1N1M0 & 1 & no & yes & recurr. & Met918Thr & 10 & $w$ & + & + & - \\
\hline 10 & $\mathrm{~F}$ & 2000 & 55 & normal & normal & T1NOM0 & 5 & no & no & $\mathrm{DF}$ & Met918Thr & 20 & $w$ & - & + & - \\
\hline 11 & $\mathrm{M}$ & 2002 & 40 & increased & increased & T1N1M0 & 3 & yes & yes & recurr & Met918Thr & 5 & $\mathrm{w}$ & - & + & + \\
\hline 12 & $\mathrm{~F}$ & 1999 & 61 & increased & increased & T2NOMO & 6 & no & no & high CT & Met918Thr & 30 & $w$ & + & + & + \\
\hline 13 & $M$ & 1999 & 65 & increased & increased & T4N1M0 & 3 & yes & yes & died & Met918Thr & 75 & $w$ & + & - & + \\
\hline 14 & $\mathrm{M}$ & 1996 & 18 & normal & normal & T3N1M0 & 9 & no & yes & recurr. & $\begin{array}{c}\text { Gly911Asp+Met918Thr+ } \\
\text { Glu921Lys }\end{array}$ & 46 & w & + & + & - \\
\hline 15 & $\mathrm{~F}$ & 2001 & 77 & normal & normal & T1NOM0 & 4 & no & no & $\mathrm{DF}$ & Val591lle+Met918Thr & 20 & $p$ & - & - & - \\
\hline 16 & $\mathrm{M}$ & 1998 & 66 & increased & increased & $\mathrm{T} 2 \mathrm{~N} 1 \mathrm{M} 0$ & 2 & yes & yes & recurr. & Thr930Met & 40 & w & + & + & + \\
\hline 17 & $\mathrm{M}$ & 1999 & 60 & increased & increased & T4N1M0 & 1 & yes & yes & recurr. & Ser922Pro & 25 & $p$ & - & - & - \\
\hline 18 & $\mathrm{~F}$ & 2002 & 40 & normal & increased & T1NOMO & 2 & no & yes & recurr. & Cys630Arg & 10 & $w$ & - & + & - \\
\hline 19 & $\mathrm{~F}$ & 2000 & 61 & increased & increased & T4N1Mx & 0.5 & yes & yes & recurr. & 6bp del632-633 & 35 & $\mathrm{w}$ & + & + & - \\
\hline 20 & $\mathrm{M}$ & 2004 & 43 & increased & increased & $\mathrm{T} 4 \mathrm{~N} 1 \mathrm{Mx}$ & 1 & no & yes & recurr. & 6bp del632-634 & 20 & $w$ & + & - & - \\
\hline 21 & $\mathrm{~F}$ & 2000 & 59 & normal & increased & T4N1MX & 3 & no & yes & recurr. & 6bp del632-635 & 42 & $w$ & + & - & + \\
\hline 22 & $\mathrm{M}$ & 2001 & 76 & normal & normal & T1NOMX & 4 & no & no & $\mathrm{DF}$ & Ala883Phe & 20 & $w$ & - & + & + \\
\hline 23 & $M$ & 1998 & 56 & increased & increased & T4N1M1 & 1 & yes & yes & recurr. & Ala883Ser & 50 & $p$ & + & + & - \\
\hline 24 & $\mathrm{~F}$ & 2001 & 51 & normal & normal & T1NOMO & 4 & no & no & $\mathrm{DF}$ & $\mathrm{n}$ & 10 & $p$ & - & - & - \\
\hline 25 & $\mathrm{~F}$ & 1998 & 57 & normal & normal & T1NOM0 & 7 & no & no & $\mathrm{DF}$ & $\mathrm{n}$ & 20 & $p$ & + & - & - \\
\hline 26 & $\mathrm{~F}$ & 2000 & 60 & increased & increased & $\mathrm{T} 4 \mathrm{~N} \times \mathrm{Mx}$ & 0 & yes & yes & died & $\mathrm{n}$ & 47 & w & + & + & - \\
\hline 27 & $\mathrm{~F}$ & 1998 & \begin{tabular}{|l|}
48 \\
\end{tabular} & normal & normal & T1N0M0 & 6 & no & no & DF & $\mathrm{n}$ & 10 & $w$ & - & + & - \\
\hline
\end{tabular}




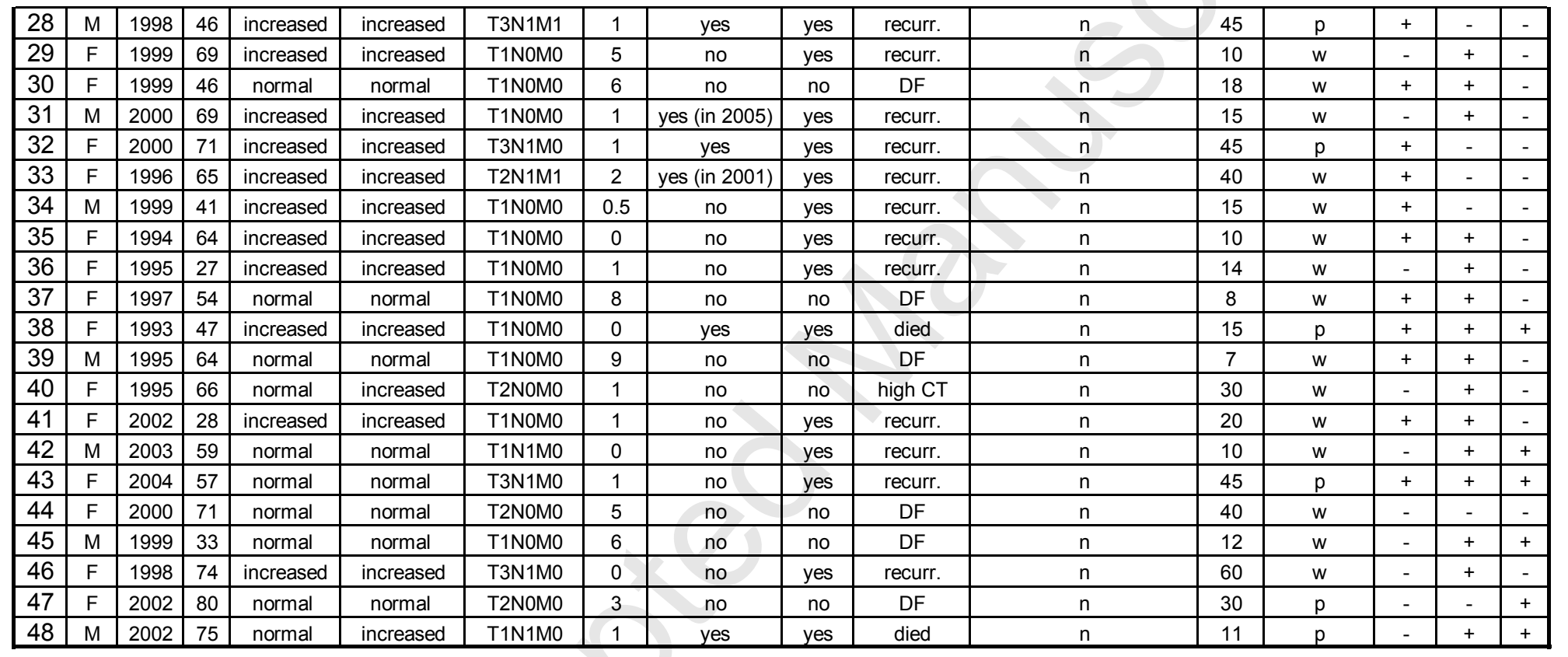


Tab.2: Detection rate of the RET proto-oncogene somatic mutations

\begin{tabular}{|c|c|c|c|c|}
\hline \multicolumn{2}{|c|}{ Type of mutation } & number & $\%$ & $\%$ of mutations \\
\hline \multirow{4}{*}{ exon 16} & Met918Thr & 13 & 27.1 & 56.5 \\
\hline & Thr930Met & 1 & 2 & \multirow{8}{*}{43.4} \\
\hline & Ser922Pro & 1 & 2 & \\
\hline & Gly911Asp,Met918Thr,Glu921Lys & 1 & 2 & \\
\hline exon $10+16$ & Val591lle, Met918Thr & 1 & 2 & \\
\hline \multirow{2}{*}{ exon 11} & Cys630Arg & 1 & 2 & \\
\hline & del 6bp 632-633 & 3 & 6.1 & \\
\hline \multirow{2}{*}{ exon 15} & Ala883Phe & 1 & 2 & \\
\hline & Ala883Ser & 1 & 2 & \\
\hline \multicolumn{2}{|c|}{ total with mutation } & 23 & 47.9 & 100 \\
\hline \multicolumn{2}{|c|}{ total no mutation } & 25 & 52.1 & 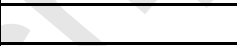 \\
\hline \multicolumn{2}{|c|}{ total tumors } & 48 & 100 & $\Delta$ \\
\hline
\end{tabular}


Tab 3.: Clinical and pathological characteristics with respect of the RET somatic mutation occurrance

\begin{tabular}{|c|c|c|c|c|}
\hline \multicolumn{2}{|c|}{ Characteristics } & mutation $(n=23)$ & no mutation $(n=25)$ & $\mathbf{P}$ \\
\hline \multirow{2}{*}{ sex } & male & $12(63,1 \%)$ & $7(36,8 \%)$ & \multirow{2}{*}{ a-n.s. } \\
\hline & female & $11(37,9 \%)$ & $18(62,1 \%)$ & \\
\hline \multicolumn{2}{|c|}{ age at diagnosis } & $51,17 \pm 16,21$ & $56,88 \pm 14,60$ & b-n.s. \\
\hline \multirow{2}{*}{$\begin{array}{c}\text { serum calcitonin level } \\
\text { after operation }\end{array}$} & normal & $9(40,9 \%)$ & $13(59,1 \%)$ & \multirow{2}{*}{ a - n.s. } \\
\hline & increased & $14(53,8 \%)$ & $12(46,2 \%)$ & \\
\hline \multirow{2}{*}{$\begin{array}{c}\text { serum calcitonin level } \\
\text { at last control }\end{array}$} & normal & $7(38,9 \%)$ & $11(61,1 \%)$ & \multirow{2}{*}{ a - n.s. } \\
\hline & increased & $16(53,3 \%)$ & $14(46,7 \%)$ & \\
\hline \multirow{4}{*}{$\begin{array}{c}\text { Pathological TNM } \\
\text { (pTNM) classification } \\
\text { at operation }\end{array}$} & $\mathrm{T} 1$ & $8(33,3 \%)$ & $16(66,7 \%)$ & \multirow{4}{*}{$a-P=0,022$} \\
\hline & $\mathrm{T} 2$ & $4(50 \%)$ & $4(50 \%)$ & \\
\hline & T3 & $2(33,3 \%)$ & $4(66,7 \%)$ & \\
\hline & $\mathrm{T} 4$ & $9(90 \%)$ & $1(10 \%)$ & \\
\hline \multicolumn{2}{|c|}{ developed distant metastasis } & $10(58,8 \%)$ & $7(41,2 \%)$ & a-n.s. \\
\hline \multicolumn{2}{|c|}{ developed local metastasis } & $16(51,6 \%)$ & $15(48,4 \%)$ & a-n.s. \\
\hline \multirow{4}{*}{ clinical outcome } & disease free & $6(40 \%)$ & $9(60 \%)$ & \multirow{4}{*}{ a - n.s. } \\
\hline & \begin{tabular}{|l|} 
high calcitonin \\
\end{tabular} & $1(50 \%)$ & $1(50 \%)$ & \\
\hline & recurrence & $15(55,6 \%)$ & $12(44,4 \%)$ & \\
\hline & died & $1(25 \%)$ & $3(75 \%)$ & \\
\hline \multicolumn{2}{|c|}{ disease free interval } & $2,85 \pm 2,11$ & $2,78 \pm 2,86$ & b-n.s. \\
\hline \multicolumn{2}{|c|}{ tumor size $(\mathrm{mm})$} & $29,48 \pm 16,57$ & $23,48 \pm 15,78$ & b-n.s. \\
\hline \multirow{2}{*}{ tumor differentiation } & well & $16(48 \%)$ & $17(51,5 \%)$ & \multirow{2}{*}{ a - n.s. } \\
\hline & poorly & $7(46,7 \%)$ & $8(53,3 \%)$ & \\
\hline \multicolumn{2}{|c|}{ presence of vascular invasion } & $15(53,6 \%)$ & $13(46,4 \%)$ & a-n.s. \\
\hline \multicolumn{2}{|c|}{ presence of amyloid } & $16(48,5 \%)$ & $17(51,5 \%)$ & a-n.s. \\
\hline \multicolumn{2}{|c|}{ presence of necrosis } & $8(57,1 \%)$ & $6(42,9 \%)$ & a-n.s. \\
\hline
\end{tabular}

